\title{
Primary MALT lymphomas of the stomach: A pathological study of 18 cases
}

\author{
I. Venizelos, D. Tamiolakis ${ }^{1}$, M. Lambropoulou ${ }^{2}$, S. Bolioti ${ }^{1}$, S. Nikolaidou ${ }^{1}$, G. Alexiadis ${ }^{2}$ and \\ N. Papadopoulos ${ }^{2}$
}

Department of Pathology. Ippokration Hospital of Salonica. ${ }^{I}$ Department of Cytology. General Hospital of Chania. ${ }^{2}$ Department of Histology-Embryology. Democritus University of Thrace. Greece

\section{RESUMEN}

Objetivo: es difícil que alguien que padezca un linfoma gástrico de tipo MALT pueda librarse de la enfermedad,... a menos que se le trate con medicación para Helicobacter pylori.

Material y métodos: se analizó una cohorte de 18 pacientes. Diez huéspedes tenían linfoma gástrico de tipo MALT y se trataron con resección gástrica como tratamiento inicial. Ocho recibieron antibióticos frente a Helicobacter pylori como tratamiento inicial. En los 18 pacientes se evaluaron la presencia de Helicobacter pylori, los hallazgos endoscópicos y los rasgos patológicos. Se realizó una inmunohistoquímica para valorar el bcl-2 y el p53.

Resultados: los pacientes con linfoma MALT de grado bajo: a) dieron positivo a Helicobacter pylori (5 de 5); b) tenían una lesión superficial (5 de 5); c) no tenían afectados los ganglios linfáticos (5 de 5); y d) se estadificaron a la baja por comparación con los pacientes con tumores de grado alto. El bcl-2 fue positivo en 4 de los 5 tumores de grado bajo y el p53 fue positivo en 12 de 13 de los de grado alto. El estudio de los pacientes durante un seguimiento de 5 años $(n=18)$ reveló que todos los tumores menos uno de grado bajo siguieron siendo superficiales sin progresión. Estos tumores eran bcl-2+/p53-, mientras que el único con inmunofenotipo bcl-2+/p53+ progresó hasta convertirse en un tumor de bajo grado ulcerado tras la desaparición de Helicobacter pylori. Se observó una regresión completa en 6 de los 8 pacientes del grupo no tratado con cirugía $(n=8)$ tras la erradicación de Helicobacter pylori. Estos tumores eran superficiales, de bajo grado, con ganglios negativos y bcl-2+/p53 no concluyente $(\mathrm{n}=2)$; superficiales, de bajo grado, con ganglios negativos y bcl-2+/p53$(\mathrm{n}=2)$, y ulcerativos, de grado alto, con ganglios negativos y bcl$2+/$ p53- $(n=2)$. Los dos tumores persistentes eran ulcerativos, de grado alto con ganglios negativos y bcl-2+/p53+.

Conclusión: el linfoma gástrico de tipo MALT, Helicobacter pylori-positivo, superficial, de grado bajo y bcl-2+/p53- desaparece tras la erradicación de Helicobacter pylori.

Palabras clave: Linfoma gástrico MALT. Bcl2 oncogenes. p53 oncogenes. Inmunohistoquímica.

\begin{abstract}
Aim: it is doubtful that whoever is suffering from gastric MALT lymphoma will escape from the disease, if treated with medication against helicobacter pylori.

Material and methods: a cohort of 18 patients was analysed. Ten hosts had primary gastric malt lymphoma and were treated with gastric resection as the initial therapy. Eight hosts received antibiotics against Helicobacter pylori as the initial treatment. In all 18 patients Helicobacter pylori status, endoscopic findings and pathology features were evaluated. Immunohistochemistry was performed to assess the bcl-2 and p53 status.

Results: patients with low grade MALT lymphoma: a) were $\mathrm{He}$ licobacter pylori positive (5 of 5); b) had a superficial lesion (5 of 5); c) had no lymph node involvement (5 of 5); and d) were downstaged by comparison to patients with high grade tumor. $\mathrm{Bcl}-2$ was positive in 4 of 5 low grade tumors, and p53 was positive in 12 of 13 high grade ones. Investigation of patients with 5-year follow up $(n=18)$ revealed that all but one low-grade tumors remained superficial with no progression. These tumors were bcl-2+/p53-, and the one with a bcl-2+/p53+ immunophenotype progressed to an ulcerated lowgrade tumor after disappearance of Helicobacter pylori. Complete regression was found in 6 of 8 patients from the non surgically treated group $(n=8)$ after Helicobacter pylori eradication. These tumors were superficial/low grade/node negative/bcl-2+/p53 inconclusive $(\mathrm{n}=2)$, superficial/low grade/node negative/bcl$2+/ p 53-(n=2)$, and ulcerative/high grade/node negative/bcl$2+/ p 53-(n=2)$. The two persistent tumors were ulcerative/high grade/node negative/bcl-2+/p53+.
\end{abstract}

Conclusion: gastric MALT lymphoma Helicobacter pylori+/superficial/low grade/bcl-2+/p53- will disappear after Helicobacter pylori eradication.

Key words: Gastric MALT lymphoma. Bcl2 oncogene. p53 oncogene. Inmunohistochemistry.

Venizelos I, Tamiolakis D, Lambropoulou M, Bolioti S, Nikolaidou S, Alexiadis G, Papadopoulos N. Primary MALT lymphomas of the stomach: a pathological study of 18 cases. Rev Esp Enferm Dig 2007; 99: 270-274.

Recibido: 25-09-06.

Aceptado: 09-01-07.

Correspondencia: Nikolas Papadopoulos. Democritus University of Thrace. Dragana, 68, 100 Alexandroupolis, Greece. Fax: +3025510-39889. email:npapad@med.duth.gr

\section{INTRODUCTION}

The gastrointestinal tract is the most common site of the primary extranodal lymphomas and gastric lym- 
phomas are featured in the majority of the cases (1). However gastric lymphoma accounts for only 1-10\% of all gastric malignant neoplasms (2).

Since the first publication of Isaacson and Wright (3), the concept of low grade (LG) B-cell lymphoma of mucoca-associated lymphoid tissue (MALT) seems to have become widely accepted and has been incorporated into the new classification scheme (REAL) as extranodal marginal zone B-cell lymphoma (4). In addition, transformation to high grade (HG) lymphomas from LG MALT lesions has been described by many authors (2,5-7).

Acquired MALT accumulates in the stomach after $\mathrm{He}$ licobacter pylori $(\mathrm{Hp})$ infection, and $\mathrm{Hp}$ can be found in most of the cases. More recently, eradication of $\mathrm{Hp}$ has been added to the potentially effective stomach-conserving therapies for LG-MALT-lymphomas (8-12).

Compared with node-based lymphomas, these MALT lymphomas of the stomach are recognized as a distinct disease entity with a characteristic presentation, histological spectrum and clinical behaviour (13). They differ in at least three instances: a) in localized stages, they behave as focal tumors and may, therefore, be curable by radical resection; b) most tumors of LG malignancy have a distinct morphology; and c) relapse of the disease may occur exclusively within the gastrointestinal tract, even long after remission (5).

The over expression of p53 protein has been recently reported in $\mathrm{HG}$ gastric lymphomas $(2,14)$. An inverse relationship between bcl-2 protein expression and p53 expression in primary gastric lymphomas has been reported and bcl-2 positivity was found to decrease whereas p53 positivity increased significantly as the histologic grade advances (2).

Although gastric lymphomas are not rare in our country, there are few detailed studies in this subject. The aim of this retrospective study is to reinvestigate primary gastric lymphomas and characterize them histopathologically and immunophenotypically. The expression of bcl-2 oncoprotein and p53 oncogene were evaluated in the same cases, using immunohistochemical methods.

\section{MATERIAL AND METHODS}

During the period from 1990 to 2000 ten patients with primary malt lymphoma were retrospectively analysed and underwent gastric resection as initial treatment. Eight patients with malt lymphoma who received antibiotics against Helicobacter pylori ( $\mathrm{Hp}$ ) were also included in the study. All 8 patients were positive for $\mathrm{Hp}$ and were investigated prospectively. Writen informed consent was obtained from each subject. In all 18 patients the presence of $H p$, endoscopic findings, pathologic findings of the biopsy and resected specimen, and immunohistochemical expression of bcl-2, p53, CD3, and CD20 antigens were evaluated. $\mathrm{Hp}$ infection was diagnosed by biopsy, the urease test, histol- ogy, and culture in patients receiving antibiotics, and was diagnosed histologically in patients who underwent surgery. Treatment included omeprazole $20 \mathrm{mg}$ and amoxicillin $1.5 \mathrm{~g}$ twice a day plus clarithromycin $800 \mathrm{mg}$ twice a day, for two weeks.

Histologic sections prepared from paraffin blocks were routinely stained with hematoxylin-eosin (HE) and examined through a standard light microscope. The cases were divided into 4 groups according to the MALT lymphoma concept (15). The histologic features of MALT lymphoma proposed by Issacson are as follows: low grade lymphoma shows proliferation of centrocyte-like cells that occasionally invade the glands (lymphoepithelial lesions) and have a marked tendency toward plasma cell differentiation. The presence of lymphoid follicles in or around the tumor is a constant finding. In high grade MALT lymphoma, large, transformed lymphoid cells show diffuse proliferation with or without areas of low grade MALT lymphoma (16). The lymphoid infiltration in gastric biopsy specimens were classified according to the criteria of Wotherspoon et al. (11). To assess changes on repeat biopsy, the confidence in a diagnosis of lymphoma was expressed on a scale of 0-5 (15). Patients were staged by physical and ORL examinations, blood tests, ultrasonography, whole-body computed tomography (CT) scanning, and endoscopic ultrasonography of the gastric lesion, according to modified Ann Arbor classification criteria (17-20).

Expression of Bcl-2 protein (Bcl-2, DAKO), p53 protein (D0-7, DAKO), CD3 (DAKO), and CD20 (DAKO), was also assessed in paraffin embedded sections. For immunoperoxidase staining of Bcl-2, p53, CD3, and CD20, we applied the microwave oven heating technique, which has been shown to be effective for the retrieval of masked epitopes. The findings were classified as follows: (-), no reactive cells; $(+)$, scattered positive cells; $(2+)$, nests of positive cells; $(3+)$, diffuse positive cells.

The antibiotic-treated group was then prospectively followed with regular endoscopic biopsy, and each response was histologically evaluated and graded using the histologic scoring system proposed by Wotherspoon et al. (11): with a posttreatment score $<3$ evidencing lymphoma regression, a score of 3 indicating partial response, and a score of 4-5 indicating no response. Follow-up was carried out every 3-6 months, with clinical evaluation; upper endoscopy plus multiple biopsies for histologic, bacteriologic, and immunohistochemical studies; and endoscopic ultrasonography (EUM 2 or 3, Olympus).

Modified Giemsa (MG) staining was performed using a mixture of $60 \mathrm{ml}$ distilled water and $2.6 \mathrm{ml} \mathrm{MG}$ solution. After the treatment of sections with this solution, they were left overnight and then treated with $1 \%$ acetic acid. An immunohistochemical study was performed using a Labeled Streptavidin Biotin (LSAB) Universal kit (DAKO) according to the instructions of the manufacturer and 3-amino, 9ethyl-carbazole (AEC) was used as chromogen. The primary antibodies used are prediluted forms of anti-bcl-2 protein, p53 oncoprotein, CD20, and CD3 antibodies. Five- 
micron thick paraffin sections were left overnight in $37^{\circ} \mathrm{C}$ in autoclave for overnight. After deparaffinization for 7 minutes, they were treated with $800 \mathrm{KW}$ antigen retrival. The immunostained slides were examined by light microscopy. The staining was considered positive where more than $10 \%$ of the lymphoma and neoplastic plasma cells were stained strongly. When less than $10 \%$ of the cells were stained positively, it was scored as weak positivity.

Data were evaluated with the chi-square or the Fisher exact test. A p value $<0.05$ was considered statistically significant.

\section{RESULTS}

Of the 10 patients with primary malt lymphoma who were surgically treated, 1 was classified as harboring low grade tumor and 9 as harboring high grade tumors (low $>$ high:2, low < high:4, high:3 patients; low > high describes low grade B-cell lymphomas of MALT with small areas of high grade lymphoma and low $<$ high describes high grade B-cell lymphomas with small areas of low grade components of MALT, high describes pure high grade lymphomas). The age of the patients with high grade components ranged from 34 to 81 years (median, 60.2 years), and the male-to-female ratio was 9:5. The correlations between the histologic type of lymphoma and other factors, such as the presence of $\mathrm{Hp}$, macroscopic tumor type, depth of invasion, lymph node involvement, clinical stage, and expression of Bcl-2 (Fig. 1), and p53 (Fig. 2), are shown in tables I and II.

All 10 patients were $H p$ positive, the one low grade tumor was superficial. All the high grade tumors were ulcerated, no lymph node involvement by any tumor was present. All patients were staged as EI, the one low grade tumor was bcl-2 positive and p53 negative, and all the high grade tumors were bcl-2 +/p53+.

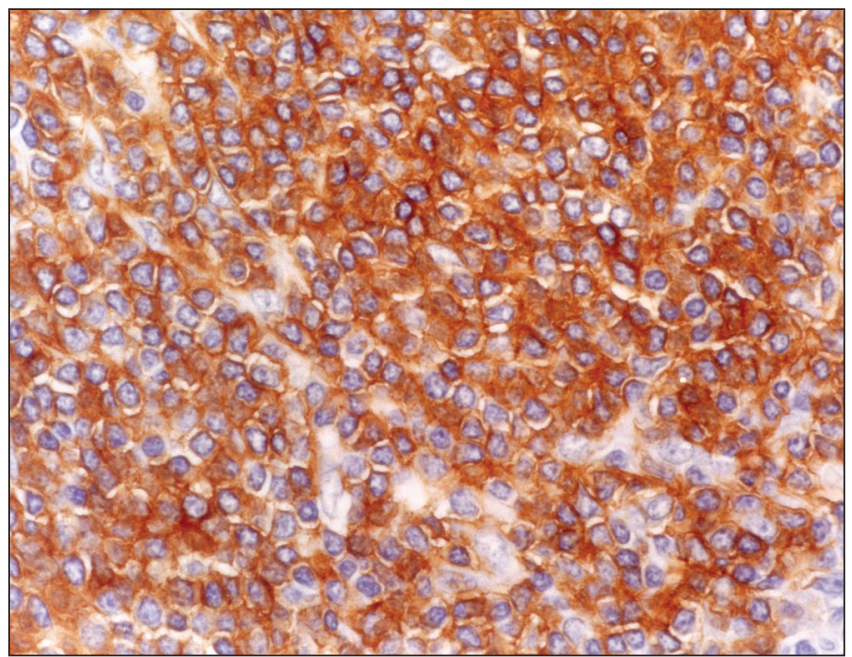

Fig. 1. MALT-type gastric lymphoma. Tissue section. Bcl-2 expression. Immunostain X 200 .

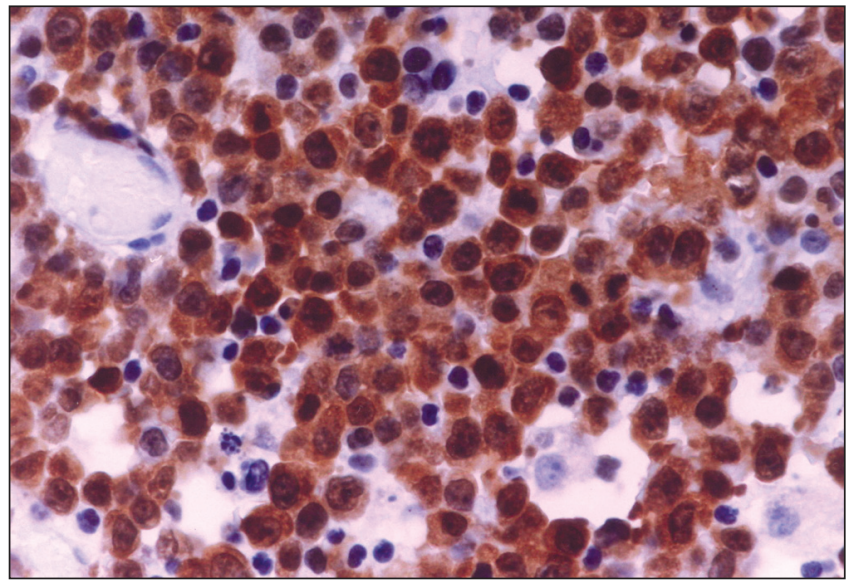

Fig. 2. MALT-type gastric lymphoma. Tissue section. p53 expression. Immunostain X 200 .

Of the 8 patients harboring MALT lymphoma who were treated with antibiotics, 4 were classified in the low grade tumor category and 4 in the high grade category (low > high:1, low < high:2, high:1 patient). All were $H p$ positive; all low grade tumors were superficial, all high grade tumors were ulcerated; no lymph node involvement was present by the CT-scanning; all patients were staged as EI; one low grade tumor was bcl-2 negative; three high grade tumors were p53 positive; the one low grade/bcl-2 negative tumor was positive by $\mathrm{p} 53 \mathrm{im}-$ munostaining; two low grade tumors were bcl-2 inconclusive/p53 positive).

Table I. Characteristics of patients who were treated with antibiotics against $H p$

\begin{tabular}{cccccc}
\hline Case & Macroscopic features & Grade & Nodes & bcl-2 & p53 \\
\hline 1 & Superficial & Low & 0 & - & - \\
2 & Superficial & Low & 0 & $+/-$ & + \\
3 & Superficial & Low & 0 & $+/-$ & + \\
4 & Superficial & Low & 0 & - & + \\
5 & Ulcerative & High & 0 & + & + \\
6 & Ulcerative & High & 0 & + & + \\
7 & Ulcerative & High & 0 & + & + \\
8 & Ulcerative & High & 0 & + & + \\
\hline
\end{tabular}

Table II. Characteristics of patients who were treated with surgery

\begin{tabular}{cccccc}
\hline Case & Macroscopic features & Grade & Nodes & $b c l-2$ & $p 53$ \\
\hline 1 & Superficial & Low & 0 & + & - \\
2 & Ulcerative & High & 0 & + & + \\
3 & Ulcerative & High & 0 & + & + \\
4 & Ulcerative & High & 0 & + & + \\
5 & Ulcerative & High & 0 & + & + \\
6 & Ulcerative & High & 0 & + & + \\
7 & Ulcerative & High & 0 & + & + \\
8 & Ulcerative & High & 0 & + & + \\
9 & Ulcerative & High & 0 & + & + \\
10 & Ulcerative & High & 0 & + & + \\
\hline
\end{tabular}


All 18 tumors were CD20 positive/ CD3 negative.

A 5-year follow-up of all 18 subjects disclosed that all low grade tumors except one, remained superficial with no progression and these tumors were bcl-2+/p53; the one exception from the rule was positive by both antigens immunostaining. This patient developed an ulcerated low grade lesion after eradication of $\mathrm{Hp}$.

Complete regression was found in 6 out of 8 not surgically treated patients, after $H p$ infection was no more present; these tumors were superficial/low grade/node negative/bcl-2+/p53 inconclusive $(\mathrm{n}=2)$, and superficial/low grade/node negative/bcl-2+/p53- $(\mathrm{n}=4)$. The remaining two were ulcerative/high grade/node negative/bcl-2 $+/ \mathrm{p} 53+$.

There was a statistically significant difference between p53 positivity between low grade and high grade cases ( $p$ $=0.0302$ for overall positivity, $\mathrm{p}=0.0036$ for only strong positivity). In high grade cases positivity of bcl2 and p53 oncogens were compared, p53 expression was found higher than bcl2 expression and the difference between the positivity of these oncogens in high grade cases, was statistically significant $(p=0.0422)$. There was no statistically significant difference between their expression in low grade tumors.

\section{DISCUSSION}

Gastric lymphomas account for the majority of the extranodal lymphomas and until the 1980s, all of the NHL classifications were unavailable for gastrointestinal lymphomas (2). A new classification for these lymphomas according to LG MALT concept, was proposed by Isaacson et al. in 1983 (3) and since then, this classification has become widely used. Later, transformation from LG lesions to HG lymphoma was described by some authors $(2,5,21)$. In addition, others described mixed grade (LG B-cell lymphoma of MALT with a focal HG component) (22). HG gastric MALT lymphomas were reported to be more frequent than LG lesions $(5,19,23)$. In Nakamura's study, among 233 cases, $43 \%$ of the cases were HG, $30 \%$ were $\mathrm{LG}, 12 \%$ were $\mathrm{LG}$ with focal $\mathrm{HG}, 6 \%$ other $\mathrm{B}, 6 \%$ other T-cell lymphomas (9). In Chan's series, 12 of 48 cases were LG, 26 were HG and 10 were mixed LG and HG (5). However, His et al. found LG MALT lymphomas more (22 of 48 cases) (6). By contrast, some investigators reported that not MALT type, but the diffuse large cell type of lymphoma, was highest in incidence among primary gastric lymphomas in Japan (24).

In the study of Nakamura, among macroscopic types, most of tumors that appeared as mass forming type proved to be HG tumors (2). As the MALT accumulates in stomach after $H p$ infection, $H p$ can be found in most of the lymphoma cases $(10,11)$. In our study $H p$ was positive in all 18 cases $(100 \%)$.

The vast majority of primary gastric lymphomas are of B-cell origin. T-cell tumors are very rare $(2,22,24)$. In our series all lymphomas demonstrated a B-cell immunophenotype as they were stained positive with CD20.

The bcl-2 proto-oncogene, which was cloned from the break-point region of $\mathrm{t}(14 ; 18)$ chromosomal translocation is frequently observed in the follicular lymphoma and the expression of bcl-2 protein has been detected in various nodal lymphomas. However, few articles have evaluated the expression of bcl-2 protein by immunohistochemical technique in primary lymphomas. The frequency of bcl-2 positivity in these studies is different according to grade $(2,7)$. In the largest series, bcl-2 protein expression was detectable in $68 \%$ of primary gastric lymphoma cases.

The overexpression of $\mathrm{p} 53$ protein either with or without a gene mutation has been reported in various tumors including nodal lymphomas. However, immunohistochemical analysis of p53 expression in gastric lymphomas has been done in a few studies $(2,14)$.

In conclusion, primary gastric lymphomas comprise a group of distinctive clinicopathologic entities. Most of LG B-cell gastric lymphomas are of MALT type and appear to arise in MALT aquired as a reaction to $H p$ infection. LG MALT NHL may undergo HG transformation, and LG component can be shown in HG MALT lesions. There is an inverse correlation between the expression of bcl-2 and p53 proteins in gastric lymphomas. p53 oncoprotein positivity increases where bcl-2 oncoprotein positivity decreases as the histologic grade advances. This result suggests that the expression of bcl-2 and p53 may be associated with a transition from $\mathrm{LG}$ to $\mathrm{HG}$ tumors.

\section{REFERENCES}

1. Isaacson P. Recent developments in our understanding of gastric lymphomas. Am J Surg Pathol 1996; 20 : S1-S7.

2. Nakamura S, Akazawa K, Kinukawa N, et al. Inverse correlation between the expression of bcl-2 and p53 proteins in primary gastric lymphoma. Human Pathol 1996; 27 (3): 225-33.

3. Isaacson $\mathrm{P}$, Wright $\mathrm{DH}$. Malignant lymphoma of mucosa-associated lymphoid tissue. A distinctive type of B-cell lymphoma. Cancer 1983; 52: 1410-6.

4. Harris NL, Jaffe ES, Stein H, et al. A revised Eropean-American clessification of lymphoid neoplasms: a proposal from the International Lymphoma Study Group. Blood 1994; 84: 1361-92.

5. Chan JK, Isaacson PG. Relationship between high-grade lymphoma and low-grade B-cell mucosa-associated lymphoid tissue lymphoma (MALToma) of the stomach. Am J Pathol 1990; 136: 1153-64.

6. His ED, Eisbruch A, Greenson JK, et al. Classification of primary gastric lymphomas according to histologic features. Am J Surg Pathol 1998; 22: 17-27.

7. Pan L, Diss TC, Cunningham D, et al. The bcl-2 gene in primary Bcell lymphoma of mucosa-associated lymphoid tissue (MALT). Am J Pathol 1989; 135: 7-11.

8. Genta RM, Hamner HW, Graham DY. Gastric lymphoid follicles in Helicobacter pylori infection: frequency, distribution and response to triple therapy. Hum Pathol 1993; 24: 577-83.

9. Nakamura S, Yao T, Aoyagi K, et al. Helicobacter pylori and primary gastric lymphoma. A histologic and immunohistochemical analysis of 237 patients. Cancer 1997; 79: 3-11.

10. Wotherspoon AC, Ortiz-Hidalgo C, Falzon MR, Isaacson PG. Helicobacter pylori-associated gastritis and primary B-cell gastric lymphoma. Lancet 1991; 338: 1175-6. 
11. Wotherspoon AC, Doglioni C, Diss TC, et al. Regression of primary low-grade B-cell gastric lymphoma of mucosa-associated lymphoid tissue type after eradication of Helicobacter pylori. Lancet 1993; 342: 575-7.

12. Nakamura S, Matsumoto $\mathrm{T}$, Suekane $\mathrm{H}$, et al. Long term clinical outcome of Helicobacter pylori eradication for gastric mucosa associated lymphoid tissue lynphoma with a reference to second line treatment. Cancer 2005; 104: 532-40.

13. Isaacson PG, Spencer J, Finn T. Primary B-cell gastric lymphoma. Hum Pathol 1986; 17: 72-82.

14. Du M, Peng H, Sihgh N, et al. The accumulation of p53 abnormalities is associated with progression of mucosa-associated lymphoid tissue lymphoma. Blood 1995; 86: 4587-93.

15. Ohashi S, Segawa K, Okamura S, et al. A clinicopathological study of gastric mucosa associated lymphoid tissue lymphoma. Cancer 2000; 88 (10): 2210-9.

16. Du MO, Isaacson PG. Recent advances in our understanding of the biology and pathogenesis of gastric mucosa-associated lymphoid tissue (MALT) lymphoma. Forum Genova 1998; 8: 162-73.

17. Musshoff K, Schmidt-Vollmer H. Proceedings: Prognosis of non Hodkin's lymphomas with special emphasis on staging classification. Z. Krebsforsch Klin Onkol Cancer Res Clin Oncol 1975; 83: 323-41.
18. Eidt S, Stolte M, Fischer R. Helicobacter pylori gastritis and primary gastric non-Hodkin's lymphomas. J Clin Pathol 1994; 47: 436-9.

19. Mones J, Gisbert JP, Borda F, Domínguez-Muñoz E; Grupo Conferencia Española de Consenso Sobre Helicobacter Pylori. Indications, diagnostic tests and Helicobacter pylori eradication therapy. Recommendations by the $2^{\text {nd }}$ Spanish Consensus Conference. Rev Esp Enferm Dig 2005; 97: 348-74.

20. Varas MJ, Fabra R, Abad R, Turro J, Espinos JC, Bargallo D, et al. Endoscopic staging of low-grade gastric MALT lymphoma. Rev Esp Enferm Dig 2006; 98: 189-95.

21. Isaacson PG. Gastrointestinal lymphoma. Hum Pathol 1994; 25: 1020-9.

22. Lavergne A, Kanavaros P, Galian A. Primary B-cell gastric lymphomas of mucosa-associated lymphoid tissue. Histological and immunohistochemical study of ten cases on surgical specimens. Histol Histopath 1992; 7: 129-36.

23. Radaszkiewicz T, Dragosics B, Bauer P. Gastrointestinal malignant lymphomas of mucosa-associated lymphoid tissue: factors relevant to prognosis. Gastrenterology 1992; 102: 1628-38.

24. Narita M, Yatabe Y, Asai J, et al. Primary gastric lymphomas: morphologic, immunohistochemical and immunogenetic analyses. Pathol Int1996; 46: 623-9. 